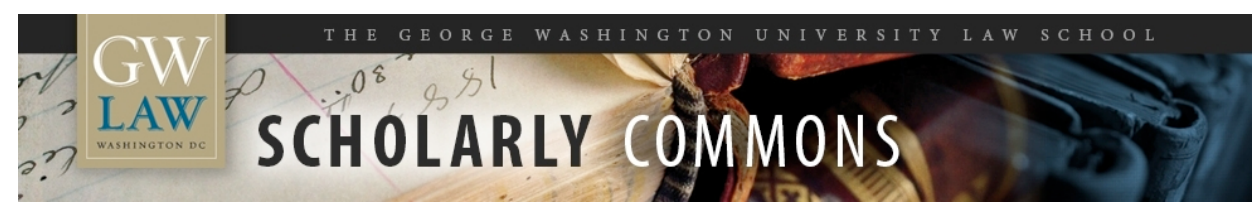

GW Law Faculty Publications \& Other Works

Faculty Scholarship

2003

\title{
Corporate Governance in China: An Overview
}

Donald C. Clarke

George Washington University Law School, dclarke@law.gwu.edu

Follow this and additional works at: https://scholarship.law.gwu.edu/faculty_publications

Part of the Law Commons

\section{Recommended Citation}

14 China Econ. Rev. 494 (2003).

This Article is brought to you for free and open access by the Faculty Scholarship at Scholarly Commons. It has been accepted for inclusion in GW Law Faculty Publications \& Other Works by an authorized administrator of Scholarly Commons. For more information, please contact spagel@law.gwu.edu. 


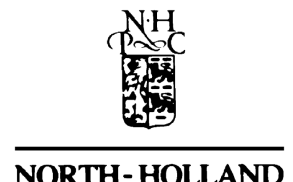

NORTH-HOLLAND
Available online at www.sciencedirect.com

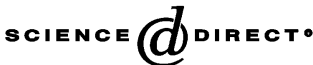

China Economic Review 14 (2003) 494-507
China Economic Review

\title{
Corporate governance in China: An overview
}

\author{
Donald C. CLARKE* \\ University of Washington School of Law, William H. Gates Hall, Box 353 020, University of Washington, \\ Seattle, Washington 98195-3020
}

Accepted 19 September 2003

Keywords: China; Corporate governance; State-owned enterprises

\section{Introduction}

Corporate governance (gongsi zhili) is a concept whose time seems definitely to have come in China. Chinese definitions of corporate governance in the abstract tend to cover the system regulating relationships among all parties with interests in a business organization, usually spelling out shareholders as a particularly important group (e.g., Liu, 1999; Yin, 1999). But Chinese corporate governance discourse in practice focuses almost exclusively on agency problems and within only two types of firms: state-owned enterprises (SOEs), particularly after their transformation into one of the corporate forms provided for under the Company Law, ${ }^{1}$ and listed companies, which must be companies limited by shares (CLS) under the Company Law. This article discusses Chinese corporate governance in this narrow sense and attempts to explain some perplexing features of its discourse, laws, and institutions (abbreviated hereinafter as "corporate governance laws and institutions" or CGLI).

A fundamental dilemma of Chinese CGLI stems from the state policy of maintaining a full or controlling ownership interest in enterprises in several sectors. The state wants the enterprises it owns to be run efficiently, but not solely for the purpose of wealth maximization. If the state owned simply for the purpose of maximizing the economic value of its holdings, there would be no need for a policy mandating state ownership of enterprises. If the enterprise would be worth more managed by another, ${ }^{2}$ the state should

* Tel.: +1-206-543-0830.

E-mail address: dclarke@u.washington.edu (D.C. Clarke).

1 Full citations of statutes mentioned in this article appear following the list of references.

2 This will often be so. Chinese firms without dominant state ownership have been shown in several studies to outperform firms with dominant state ownership (Chen, 2001; Qi, Wu, \& Zhang, 2000; Xu \& Wang, 1999). 
seek a share of that increased value by selling. A policy of wealth maximization for the state requires simply that the state acquire, maintain, or relinquish control according to whatever will realize the most wealth for the state.

Because the Chinese government clearly does not have such a policy, it follows that a necessary element of state control of an enterprise must be the use of that control for purposes other than the maximization of its wealth as a shareholder-purposes such as the maintenance of urban employment levels, direct control over sensitive industries, or politically motivated job placement. $^{3}$

This in turn creates several problems. First, many of these goals are not easily measured and there is no obvious way of balancing them one against the other. This creates monitoring difficulties. Second, the policy of continued state involvement sets up a conflict of interest between the state as controlling shareholder and other shareholders. In using its control for purposes other than value maximization, the state exploits minority shareholders who have no other way to benefit from their investment.

The major theme of this article is that the state wants to make SOEs operate more efficiently by subjecting them to a new and different set of rules - the rules of organization under the "modern enterprise system." This is what the policy of corporatization is chiefly about. Policymakers then find, however, that they must change and adjust the rules to take account of continuing state ownership. Moreover, the need to provide for the special circumstances of state sector enterprises ends up hijacking the entire Company Law so that instead of state sector enterprises being made more efficient by being forced to follow the rules for private sector enterprises (the original ambition), potential private sector enterprises are hamstrung by having to follow rules that make sense only in a heavily stateinvested economy.

Finally, corporate governance is about more than simply getting the rules right. The necessary supporting institutions must be present as well. Yet as I will argue, their existence in China cannot always be taken for granted.

\section{Background to Chinese CGLI reform}

Chinese CGLI reform, and the Company Law that is a part of it, is designed primarily to address problems within the state sector, in particular the problem of the reform of traditional state-owned enterprises (TSOEs) (Jiang, 2000, p. 21; Wang, 1999, p. 135). The need of nonstate actors for a convenient form in which to conduct business occupies a

\footnotetext{
3 Thus, we should understand as internally contradictory various proposals for the state to retain ownership of certain enterprises but to run them entirely on profit-oriented lines. Tenev and Zhang (2002, p. 133) go even further by suggesting that the state's current equity stake be replaced by an interest akin to nonvoting preferred stock. The problem of continuing state ownership of enterprises cannot be finessed so easily. Nonvoting preferred stock might be a good investment in the right circumstances, but it is hard to see why a policymaker who believes that state ownership ought to mean something would be satisfied with it or why the state should commit itself never to sell it. Indeed, in replacing its equity stake with nonvoting preferred stock, the state would be giving up its ability to use control not just to pursue noneconomic goals, but also to defend itself from exploitation by management or controlling shareholders or even to exploit other shareholders for its own economic benefit.
} 
very low priority in the minds of state policymakers, and the Company Law is thus clearly concerned more with regulating and suppressing than with fostering and nurturing. Indeed, it would be anomalous were it otherwise. There is a deep-rooted official suspicion of accumulations of wealth not controlled by the state or its officials (Fang, 2000; Kirby, 1995), coupled with the suspicion of any organized activity not firmly under state leadership (Saich, 2000). A government that bans unauthorized fishing clubs and associations for the study of antique furniture and paper cutting (MOCA, 2003) is unlikely to welcome the unbridled blossoming of organizations whose purpose is to make real money.

The TSOE is not simply another name for a corporation such as Air France that happens to be wholly owned by the state. Instead, it can be analogized for economic purposes to a cost center or a division within the loosely organized firm of "China, Inc.". There was no formal law governing industrial TSOEs until 1988, and there is still no formal law governing commercial TSOEs. There was never any need. The things that an organizational statute does - for example, the regulation of relations among creditors, investors, and managers - were simply handled through internal state administrative procedures since all three were state bodies or state employees.

For the purposes of this article, it is essential to distinguish TSOEs as defined hereSOEs as they existed under the planned economy - from enterprises organized under the Company Law that happen to be wholly state owned or controlled by the state, even though such enterprises are commonly called "state owned." A crucial element of thinking about enterprise law and the Company Law in particular is that there are important differences between the two ways of structuring SOEs.

Current policy respecting TSOEs is essentially to abolish the form by corporatizing them, i.e., converting them into some form of company governed by the Company Law: (a) a CLS, the approximate equivalent of the large stock corporation in Western countries, (b) a limited liability company (LLC), ${ }^{4}$ intended for a much smaller and more closely knit group of investors, or (c) a wholly state-owned limited liability company (WSOLLC), a special type of LLC that may be wholly owned by a state agency. This process, which does not necessarily involve privatization-it all depends on who owns the shares in the converted company - is already well under way.

The corporatization policy has many purposes. They include the raising of equity capital for SOEs following conversion to the corporate form, the expansion of state control in some sectors through leverage, and the improvement of the management of state assets through the implementation of a new organizational form. A secondary consideration in passing the Company Law was also the promotion of growth in the nonstate sector via the provision of a new organizational form. Some of these purposes are discussed below in more detail.

A final point to note about CGLI reforms is that despite talk of the state withdrawing from the economy, it is firmly committed to retaining control over enterprises in several sectors: national security-related industries, natural monopolies, sectors providing important goods and services to the public, and important enterprises in pillar industries and the

\footnotetext{
4 While all organizations under the Company Law are "limited liability companies" in the sense that their shareholders are not normally responsible for their debts, I refer here to one specific organizational form that goes by this specific name (youxian zeren gongsi).
} 
high-technology sector (JJRB, 2003). Indeed, part of enterprise reform involves a magnification of the scope of direct state control through leverage (CCP, 1999; Ma, Mok, \& Cheung, 2001). In the traditional economic system, the state (through one or more of its agencies) was the sole owner of a TSOE and exercised full control over it. Corporatization, through the institution of divisible equity shares, allows nonstate investors to contribute to the enterprise without while they remain in a minority sharing in control. The state maintains the same level of control it had before, but now over a larger pool of assets. ${ }^{5}$

\section{Purposes of corporatization: improved management through restructuring}

While corporatization has many purposes, the chief one is the promotion of higher efficiency through better management. Corporatization is intended to address through structural reform three features of the traditional system of state ownership that are blamed for the inefficiency of that sector. First, commentators criticize the supposed unity of ownership and control in the hands of the state under the old system, with the resultant imposition of non-profit-maximizing objectives on enterprise managers through "bureaucratic interference." Second, they point to the problem of conflicting objectives from multiple state agencies with authority over the enterprise. Third, they point to the absence of an effective ultimate principal with an interest in, and ability to, police managers and ensure efficient operations. I discuss these in order below.

\subsection{Ownership and control and "bureaucratic interference" in the traditional system}

It is often said that the corporate form, through its separation of ownership (in the hands of shareholders) from control (in the hands of management), will be a cure for the ills of the TSOE, which are diagnosed as stemming from the unity of ownership and control (in the hands of the state). Commentators paint a picture of harried managers trying to run a business subject to constant bureaucratic interference from the government agency in charge of the enterprise and told to meet various and conflicting goals. Corporatization is supposed to separate state ownership from state control and thereby free managers from such interference so that they can pursue efficient and profitable operations.

But both the diagnosis and the solution are fundamentally flawed. The solution is flawed because it assumes that the goal of the state owner in the new system is profits. The policy of corporatization does not involve a renunciation by the state of its ambition to remain the direct owner of enterprises in a number of sectors, and this ambition makes no sense if profits are the only objective.

The diagnosis is flawed because in the old system, ownership and control were just as separate as they are in the new because the state is an abstract collectivity and not a person. Although perhaps it could meaningfully be said to own, it must necessarily operate

\footnotetext{
5 As a former senior policymaker recently boasted, with an equity stake of a mere $6 \%$, the state controls the $94 \%$ of "social capital" in the Guangzhou Light Industrial Group, and the enterprise is classified as "state controlled" (Zhang \& Xu, 2003).
} 
through human agents. SOEs were thus always controlled, both at the enterprise level and at the level of the administrative body in charge of them, by human beings who did not own the enterprise. Devolving more power to enterprise managers or corporatizing TSOEs does not change this in the slightest.

Since the unity of ownership and control was never the problem, it follows that the separation of ownership from control cannot be the solution. Yet much Chinese commentary continues to view the separation of ownership from control not as a regrettable concomitant of the division of labor between suppliers and managers of capital (Berle \& Means, 1968), but as a positive good to be pursued for its own sake because it appears to be a necessary feature of the "modern enterprise system." Far from fearing the Berle and Means model of the corporation, in which shareholders are widely dispersed and unable to exercise any meaningful control, reform-minded commentators have seemed to welcome it. Indeed, concentrated shareholding is viewed by many as almost a perversion of the ideal of widely dispersed shareholding. ${ }^{6}$

Yet calls for government-owned enterprises to be independent of government "interference" are calls for nothing short of utter nonaccountability for management. Given that the assets were contributed to the enterprise by a government agency - certainly not by the managers - it seems reasonable for the agency to have some say in how the assets are used. The issue, of course, is what kind of targets the agency sets for the managers and how it evaluates their performance. But that is a reason to propose changes in how the state manages its agents, not to cease managing them entirely.

\subsection{Multiple objectives}

The problem of multiple objectives is certainly a real one. As a complex organization of human beings organized into various subgroups, all with their own objectives, the state does not, and arguably cannot, produce a single consistent set of targets for its agents to maximize. Moreover, control over SOEs in the traditional system was often divided among multiple agencies - one or more for labor, management, production targets, inputs, etc. none of which had to internalize the costs of the decisions of the other. Thus, it was difficult for anyone, had they been so inclined, to make and enforce a trade-off among competing objectives.

Even where there is a single monitoring body, that body may itself have several objectives. While profit maximization is a relatively straightforward index against which to measure the performance of managers, noneconomic goals such as the preservation of an industry for national security purposes are much more difficult to measure and hence to monitor for. The monitoring agency may not even know itself how the costs and benefits of achieving different state objectives should be measured and traded off against each other and thus can hardly be an effective monitor of managers charged with achieving those objectives.

Corporatization is explicitly intended to solve the problem of multiple controllers with multiple objectives. First, the interests of the various state agencies involved in the

\footnotetext{
${ }^{6}$ See, for example, Gu (2000), who proposes to limit the voting power of large shareholders, believing (incorrectly) that this is a feature of American corporate law.
} 
enterprises are reduced to a common denominator - equity - and quantified. Second, the new shareholders have only a single way in which to voice their interests - shareholder voting - in which the majority rules, thus eliminating conflicting goals. Third, despite their conflicting interests, the new shareholders now also have a common interest: distributable profits. Thus, diversification of the shareholder base, even where share ownership is not private, is intended to result in a stronger focus on the single target of profitability.

The theory has much to commend it. In practice, however, a large number of corporatized SOEs remain dominated by a single state shareholder that exercises its control either through formal channels, such as shareholder voting, or through traditional channels, such as the acknowledged authority of the Communist Party's organizational department over personnel appointments in key state-owned and state-controlled enterprises, whether or not corporatized and listed on the stock market.

\subsection{Absence of effective ultimate principal}

Many analysts of the monitoring problem in the state sector point to the absence of an ultimate principal as a key problem. According to this analysis, an agent of the state monitors the enterprise managers and another agent must monitor the monitor; however, no matter how far up the chain of monitors we go, we never run into an ultimate principal - or to be more accurate, the ultimate theoretical principal in the case of state ownership, the citizenry of China, is far too dispersed and powerless to play any real role. As a result, effective monitoring cannot take place because there is nobody in the chain of monitors with the appropriate incentives; nobody who is entitled to the increase in asset value that effective monitoring would bring about. ${ }^{7}$

Corporatization is intended to replace a pliant and negligent state owner with profitseeking shareholders that will monitor management more effectively. But was state ownership per se ever the problem? Certainly the current structure can be blamed for many problems. Even if the state as principal had mutually consistent and easily measurable goals, its agents - the monitors of the enterprise managers - might not monitor well for those goals. Actual supervision and monitoring is carried out by local officials who are appointed and salaried by local government. Even if those officials perfectly represented the interests of their principal, local government's interests can often conflict with those of the center. And in practice, of course, the effectiveness of local officials' monitoring is compromised both by their incentives to shirk and in many cases by their simple lack of skills to understand which actions would increase or decrease enterprise value.

Yet while the lack of an ultimate human owner can be a source of considerable agency costs, these costs need not be crippling. There are many successfully functioning institutions, such as nonprofit organizations (Hansmann, 1996) or industrial foundations (Thomsen, 1999), that lack an ultimate human owner at the top of a chain of monitors capable of claiming residual earnings, and there are even more-for example, governments and pension funds - that function with an ultimate human "owner" so distant as to be absent for all practical purposes.

\footnotetext{
7 For a general discussion of these issues, see Lin (2001), Liu (1999), Qi et al. (2000), Shleifer and Vishny (1997), and Yu (2001).
} 
Thus, although the absence of an ultimate owner-i.e., a human being with both control over the agent below him or her and a right to the residual - is an obstacle to efficient monitoring, it is not an insuperable one or the greatest one. It is hard, therefore, to see why state employees should be inherently incapable of monitoring effectively, given the right targets, skills, and incentives. The problem with state monitoring is far more likely to be found in the lack of these elements, not in the lack of an ultimate human principal.

Whatever the importance of a human monitor at the top of the chain, corporatization as currently practiced will not bring it about. When TSOEs are corporatized and share interests allocated or sold, the new shareholders are, for the most part, either state agencies or other entities that are owned, directly or indirectly, by the state. This is true whether or not such companies are listed on China's stock markets. Such entities may well be structured with the intention that they be profit seeking, but if they are in fact able to pursue profits effectively, that would only show that private ownership was not necessary in the first place. No amount of restructuring can eliminate the cost of the absent principal if state ownership is retained, since the latter necessarily entails the former.

\section{Continued presence of state considerations in CGLI}

Despite the reformist ambition animating the corporatization project, state sector considerations remain strong. As the owner of state sector firms, the state may reasonably stipulate how they should be run. But it is not necessary to stipulate at the same time the fine details of how nonstate parties should associate. This section will highlight two sample areas in which state sector considerations have worked backwards to shape the Company Law in ways unsuited to nonstate enterprises, in one case through prescribing unnecessary or undesirable rules and in the other through failing to do so.

\subsection{Preference for mandatory over default rules}

One goal of the corporatization project and the Company Law was to make it easier to organize for economic activity. Whether this goal has been achieved is questionable. Take, for example, the basic policy decision of whether to make the applicable rules mandatory or to allow company organizers a degree of latitude to choose the governance rules they feel are most appropriate for their circumstances. The policy choice in the current Company Law is clear: the rules are almost uniformly mandatory. As the corporate law scholar Fang (2000, p. 40) complained, "The whole Company Law is pervaded with the attitude of 'making decisions on behalf of the people.' The legislator shows an excessive self-confidence. It believes it is more intelligent than the parties and can make arrangements in their stead."

Why should participants in a business not be left to work out their own deal? Part of the answer may lie in the traditional mistrust of China's ruling elites for private solutions and an almost instinctive preference for uniformity over diversity, even if it carries no particular benefits. But much of the answer lies, once again, in the Company Law's overwhelming orientation toward the corporatization of TSOEs. The paradigmatic enterprise - or at least, the paradigmatic CLS - contemplated by the Company Law is 
not one formed by a group of private entrepreneurs who are attempting to contract among themselves for the optimal set of governance rules. It is the corporatizing TSOE. Thus, it is not surprising that the rules do not leave choices up to contracting parties; there are no contracting parties, realistically speaking, when a TSOE is transformed. TSOE transformation into a CLS is a process that takes place under governmental direction. The contours of the deal that ultimately governs the relations of the initial shareholders are not strongly shaped by market forces: there is no market for corporate control, no market for managers, and no "Wall Street option" for the state investor. Thus, it may be that there is no good reason for thinking that leaving the governance rules to "the parties" in this particular case will have economically efficient results. Indeed, it is conceivable in principle that however rigid and inappropriate some of the rules of the Company Law may be, they are better and less wasteful of state assets than the structure that state officials and incumbent TSOE managers might put together on their own if unconstrained by such rules.

At the same time, however, it is hard to see why, when state assets are not involved, decisions on a number of matters could not be left up to the parties involved. The state may wish to impose on its own enterprises, for example, rules about the reinvestment of profits $^{8}$ or the minimum and maximum number of directors, ${ }^{9}$ but why should private parties be subject to the same rules?

That legislators are capable of leaving a great deal to participants in some business enterprises is clear from the great, even excessive, latitude shown on questions of enterprise organization where the transformation of large TSOEs is not involved. The Partnership Law, the Village and Township Enterprise Law, and the regulations on stock cooperative enterprises (SCRES, 1997) are all much shorter than the Company Law and prescribe a great deal less. Indeed, there is at least one officially acknowledged form of business enterprise - a wholly owned subsidiary established by a parent enterprise - with separate legal personality that has no laws or regulations whatsoever governing its internal structure. Its legislative sanction, if it exists at all, does not extend beyond a single cryptic sentence in the Company Law providing that companies may establish subsidiaries. $^{10}$

Where the transformation of TSOEs is involved, however, legislators not unreasonably want to have rules about the end result. This is what having a state policy means. The problem is that while it might make sense for many mandatory rules to be limited only to state-owned and state-controlled companies, such a limitation would require the resurrection of a distinction between state-owned companies and non-state-owned companies, a distinction that it was a major purpose of the corporatization policy to erase. Once again, we see that because of the policy of transforming the organizational form of TSOEs into companies, the needs and imperatives of the state sector have hijacked the rules and structure of the Company Law. Instead of the intended effect - that classical company law principles should govern SOEs in order to make them efficient - the opposite has been achieved: the entire corporate sector has come to be governed, in significant degree, by principles that are needed and applicable, if at all, only to the state sector.

\footnotetext{
8 Company Law, Art. 177.

9 Company Law, Art. 112.

10 Company Law, Art. 13.
} 


\subsection{Inability to establish uniform legal standard for officers and directors}

Because the state's policy is not to maximize shareholder wealth, it is difficult to create appropriate uniform standards to which to hold managers and controlling shareholders. If controlling shareholders seek to maximize the value of their shares, the interests of minority shareholders will automatically be served. But if the state uses its control for purposes other than value maximization, it exploits minority shareholders who have no other way to benefit from their investment.

As long as state policy requires the state to remain an active investor in firms of which it is not the sole shareholder, meaningful legal protection for minority shareholders is going to mean either constraints on the state's ability to do precisely those things for which it retained control or else a de facto separate legal regime (at least as far as minority shareholder rights are concerned) for enterprises in which the state is the dominant shareholder. But a separate legal regime will require the maintenance of a strict boundary between state-controlled companies on the one hand and other companies on the other, a boundary that it was precisely the ambition of TSOE corporatization to erase. ${ }^{11}$

The failure to face this question squarely makes it extremely difficult to formulate legal rules on the duties of management. Although the Company Law imposes a duty of loyalty (zhongshi yiwu), ${ }^{12}$ there appears to be no means of enforcing this duty, and no duty of care is spelled out. Moreover, although maximization of shareholder wealth is quite frequently stated by commentators to be the proper duty of managers and controlling shareholders in non-state-controlled companies, nowhere in the entire corpus of laws and regulations on corporate governance can such a duty actually be found.

\section{Proposals for reform: power of controlling shareholders}

Probably the most common complaint about the current Company Law is that it gives too much power to controlling shareholders. As discussed above, much Chinese commentary idealizes the Berle and Means (1968) model of dispersed ownership and pictures the corporation almost as a kind of political community whose members debate policy at shareholder meetings and vote after serious consideration of the issues. Where a controlling shareholder unilaterally calls the shots, shareholder meetings are reduced to a formality, and commentators view this as a perversion of the ideal. Thus, many commentators view the presence of the dominant single shareholder (yigu duda) as a problem, and proposals to reign in their power are not just about attacking their ability to

\footnotetext{
11 The result in practice may simply be no meaningful protection for minority shareholders. Consider the remarks of the Dean of the Changjiang School of Business, who serves as an independent director:

I have never thought that the independent director is the protector of medium and small shareholders; never think that. My job is first and foremost to protect the interests of the large shareholder, because the large shareholder is the state (GAXXRB, 2003).

12 Company Law, Articles 59-62.
} 
exploit minority shareholders, but about attacking the very idea of stable control over a corporation as such.

The first problem with this picture of corporate organization is that it is profoundly unrealistic. A corporation is not a political community and cannot be expected to function like one. Corporate law considers it entirely right and proper that those with more money should have a bigger voice, and it is uneconomical for minority shareholders to spend time educating themselves on corporate issues and physically attending shareholder meetings when their vote will not affect the outcome. ${ }^{13}$

The second problem is that an ideal, however unrealistic, that is thought suitable for companies on the basis of a private ownership model simply cannot be realized in a world of extensive state ownership. The biggest dominant shareholder in China is the Chinese state. An attack on dominant share ownership per se is an attack on state ownership and cannot be expected to move beyond academic journals into legislative reality.

The third problem with this picture is that it is far from clear that concentrated ownership by itself is a bad thing anyway. Some recent studies of Chinese listed companies have found that in general, corporate performance seems to be positively correlated with concentrated ownership by institutional shareholders other than state agencies and negatively associated with dispersed ownership (Chen, 2001; Qi et al., 2000; $\mathrm{Xu} \&$ Wang, 1999). ${ }^{14}$ Thus, legal policy should be directed at eliminating abuses, not eliminating concentrated ownership as such.

\section{Institutions of corporate governance}

Any system of corporate governance depends on a set of institutions for its implementation. In the United States, for example, corporate governance of public companies depends not only on the existence of markets for equity, debt, managerial talent, and corporate control, but also on intermediate institutions (such as the financial press and the legal and accounting services industries) and legal institutions such as courts, the Securities and Exchange Commission, and private litigants. We may debate whether these institutions can play the roles assigned to them (compare, for example, Coffee, 2002, with Ribstein, 2002), but we have a pretty good idea of what they are.

It is similarly critical to any scheme of corporate governance in China that it be informed by a realistic view of the available institutions and their ability to perform the expected task. Too much cannot, for example, be expected of private plaintiff-driven litigation in the courts. Listed companies got that way because they and their officers had political backing; Chinese courts are not politically powerful and are hence reluctant to take cases involving large sums of money and powerful defendants. The Supreme People's Court allows courts to hear only a very limited class of securities-related claims (Supreme

13 On collective action problems generally, see Olson (1971).

14 Research on United States firms (e.g., McConnell \& Servaes, 1990; Wruck, 1989) has found that the relationship between firm performance and ownership concentration is an inverted V: as concentration rises, performance rises at first, but then declines as concentration rises still further. 
People's Court, 2003). Thus, if corporate governance reform is understood to mean inserting appropriate private rights of action into the Company Law, it is unlikely to lead anywhere very soon.

What about government agencies? The prime candidate here would seem to be the China Securities Regulatory Commission (CSRC); however, it is hampered by significant disabilities. First, its staff is small relative to the scale of its tasks. ${ }^{15}$ Consider the respective tasks of the CSRC and the U.S. Securities and Exchange Commission (SEC) solely in the field of listed company oversight. The main task of the SEC is the enforcement of rules regarding disclosure. It is not expected to be a guarantor of corporate profits. The CSRC, on the other hand, must enforce merit requirements that attempt to ensure the investment quality of the business as well as disclosure requirements. Moreover, its very authority to make and enforce rules regarding corporate governance has been challenged as insufficiently grounded in legislation (Sheng, 2001; Tang, 2001). So far, the challenge has been only academic, but at some point a suitably motivated court might agree.

The need to consider the role of institutions can be demonstrated by looking at the CSRC's recent regulations requiring listed companies to have at least one third of their board consist of independent directors by June 30, 2003 (CSRC, 2001). The independent directors are said to owe a duty of good faith (chengxin) and diligence (qinmian) to the company and to the entire body of shareholders. But can this duty be made meaningful in China's current legal system?

The Company Law speaks only of a duty of loyalty (zhongshi), and it is far from clear that shareholders could successfully sue for a breach. It is very unlikely that the CSRC, which does not even have the status of a regular government administrative agency, can by itself create a private right of action for shareholders against directors. It has engaged in a limited number of disciplinary actions against directors, ${ }^{16}$ but any norm that relies solely on administrative enforcement is going to be of limited value, given the CSRC's resource constraints.

As Roe (2002) has pointed out, corporate governance depends on much more than simply getting the law right. The presence of other institutions is critical. But their presence in China cannot be assumed. The financial information industry, for example, is significantly crippled by the state's continuing insistence on control over all information. Control over information is a cornerstone of the Chinese Communist Party's system of political control and is unlikely to disappear much before the Party itself. Other intermediary institutions such as law firms, accounting firms, investment banks, brokerages, and stock exchanges all exist - like any organization in China — only with government permission and cannot simply spring up in response to market demand. There is no real market for corporate control, and the market for managerial talent is still very small.

\footnotetext{
15 Professional staff probably number well under 1500 nationwide (CSRC official, July 2003, personal communication).

16 See, for example, the tale of the hapless Lu Jiahao, an academic who despite no experience in business was asked to serve as an independent director, did so without compensation, and ended up being fined 100,000 yuan by the CSRC for his troubles (Wei, 2002; Wu, 2002).
} 


\section{Conclusion}

Any discussion of corporate governance in China must take seriously the implications of the state's policy of continuing and significant involvement in enterprise ownership. Many of the problems the drafters of the Company Law sought to address are not necessarily best addressed by a statute like the Company Law or even by an institution such as legislation and government enforcement. Where they are state sector issues, it might seem almost perverse to attempt to address them through an institution designed to operate in a universe of freedom of contract and private rights. While the policy of state ownership continues, the only way to clear the road for the development of a corporate governance system appropriate for non-SOEs is for policymakers to acknowledge that a unified model is neither necessary nor desirable.

But getting the model right is not enough. Policymakers must also think clearly about the capacity of the institutions - not just legal, but social and economic - that are needed to make the model function as expected.

\section{Acknowledgements}

The author would like to express his thanks to Michael Dowdle and Barry Naughton for their thoughtful and very helpful comments on an earlier draft of this article, as well as to the Fulbright Program for its support of the research on which this article is based.

\section{References}

Berle, A., \& Means, G. (1968). The modern corporation and private property. New York: Harcourt, Brace \& World (Rev. ed.).

CCP (Chinese Communist Party). (1999, September 22). Guanyu guoyou qiye gaige he fazhan ruogan zhongda wenti de jueding (Decision on several important questions in the reform and development of state-owned enterprises). Chinese Communist Party Central Committee.

Chen, J. (2001). Ownership structure as corporate governance mechanism: Evidence from Chinese listed companies. Economics of Planning, 34, 53-71.

Coffee, J. (2002). Understanding Enron: It's about the gatekeepers, stupid (Working Paper No. 207). Columbia Law School, The Center for Law and Economic Studies.

CSRC (China Securities Regulatory Commission). (2001, August 16). Guanyu zai shangshi gongsi jianli duli dongshi zhidu de zhidao yijian (Guidance opinion on the establishment of an independent director system in listed companies).

Fang, L. (2000). Wen gu zhi xin - tan Gongsi Fa xiugai (Reviewing the old to understand the new: A discussion of reform of the Company Law). In F. Guo, \& J. Wang (Eds.), Gongsi Fa xiugai zongheng tan (An all-around discussion of reform of the Company Law) (pp. 35-42). Beijing: Falü Chubanshe.

GAXXRB (2003, January 1). Duli dongshi xiang huaping? (Are independent directors just decorative?). GangAo Xinxi Ribao (Hong Kong-Macao News Daily).

$\mathrm{Gu}, \mathrm{G}$. (2000). Gongsi Fa xiugai ying jiejue de ruogan shiji wenti (Several practical problems that should be solved in a revision of the Company Law). In F. Guo, \& J. Wang (Eds.), Gongsi Fa xiugai zongheng tan (An all-around discussion of reform of the Company Law) (pp. 57-61). Beijing: Falü Chubanshe.

Hansmann, H. (1996). The ownership of enterprise. Cambridge, MA: Belknap Press.

Jiang, P. (2000). Gongsi fa cong 19 shiji dao 20 shiji de fazhan (The development of company law from the 19th century to the 20th century). In F. Guo, \& J. Wang (Eds.), Gongsi Fa xiugai zongheng tan (An all-around discussion of reform of the Company Law) (pp. 21-28). Beijing: Falü Chubanshe. 
JJRB (2003, June 13). Heli buju tiaozheng jiegou, fazhan zhuangda guoyou jingji-fang Guowuyuan Guoyou Zichan Jiandu Guanli Weiyuanhui zhuren Li Rongrong (Rationally lay out structural adjustment, develop a great state-owned economy: A visit with the Chairman of the State Council's State Asset Supervision and Management Commission, Li Rongrong). Jingji Ribao (Economic Daily).

Kirby, W. (1995). China unincorporated: Company Law and business enterprise in twentieth century China. Journal of Asian Studies, 54, 43-63.

Lin, C. (2001). Corporatisation and corporate governance in China's economic transition. Economics of Planning, 34, 5-35.

Liu, Y. (1999). Cong xiandai qiye lilun yu chanquan lilun kan Zhongguo de gongsi zhili wenti (Looking at Chinese corporate governance issues from the standpoint of the theory of the modern firm and the theory of property rights). In Zhongguo (Hainan) Gaige Fazhan Yanjiu Yuan [China (Hainan) Reform and Development Institute] (Ed.), Zhongguo gongsi zhili jiegou (The structure of corporate governance in China) (pp. 119-132). Beijing: Waiwen Chubanshe.

Ma, N., Mok, K. H., \& Cheung, A. (2001). Advance and retreat: The new two-pronged strategy of enterprise reform in China. Problems of Post-Communism, 48, 52-61.

McConnell, J., \& Servaes, H. (1990). Additional evidence on equity ownership and corporate value. Journal of Financial Economics, 27, 595-612.

MOCA (People's Republic of China Ministry of Civil Affairs). (2003, June 6). Gonggao (Bulletin) No. 41. Available: http://www.mca.gov.cn/news/shtuan41.html (Last visited June 28, 2003).

Olson, M. (1971). The logic of collective action: Public goods and the theory of groups. Cambridge, MA: Harvard University Press.

Qi, D., Wu, W., \& Zhang, H. (2000). Shareholding structure and corporate performance of partially privatized firms: Evidence from listed Chinese companies. Pacific-Basin Finance Journal, 8, 587-610.

Ribstein, L. (2002). Market vs. regulatory responses to corporate fraud: A critique of the Sarbanes-Oxley Act of 2002. Journal of Corporation Law, 28, 1-67.

Roe, M. (2002). Corporate law's limits. Journal of Legal Studies, 31, 233-271.

Saich, A. (2000, March). Negotiating the state: The development of social organizations in China. China Quarterly, (161), 124-141.

SCRES (State Commission on Reform of the Economic System). (1997, August 7). Guanyu fazhan chengshi gufen hezuozhi qiye de zhidao yijian (Guidance opinion on the development of urban stock cooperative enterprises).

Sheng, X. (2001). Woguo zhengquan jianguan falü zhidu moshi (The model for China's securities regulatory legal system). Xiandai Faxue (Modern Law Science), No. 3, 116-120.

Shleifer, A., \& Vishny, R. (1997). A survey of corporate governance. Journal of Finance, 52, 737-783.

Supreme People's Court of the People's Republic of China. (2003, January 9). Guanyu shenli zhengquan shichang yin xujia chenshu yinfa de minshi peichang anjian de ruogan guiding (Several provisions on the adjudication of civil suits for damages arising out of false representations in securities markets).

Tang, X. (2001, November 18). Zhongguo shangshi gongsi zhili huanjing de xin fazhan (New developments in the corporate governance environment for Chinese listed companies). Paper presented at 21 st Century Commercial Law Forum, Tsinghua Univ., Beijing, China.

Tenev, S., \& Zhang, C. (2002). Corporate governance and enterprise reform in China. Washington, DC: World Bank and the International Finance Corporation.

Thomsen, S. (1999). Corporate ownership by industrial foundations. European Journal of Law and Economics, 7 (2), $117-136$.

Wang, B. (1999). Gufen youxian gongsi zuzhi jigou de fa de shitai kaocha yu lifa keti (A study of the current legal situation of the organizational structure of companies limited by shares and the legislative program for them). In Zhongguo (Hainan) Gaige Fazhan Yanjiu Yuan [China (Hainan) Reform and Development Institute] (Ed.) Zhongguo gongsi zhili jiegou (The structure of corporate governance in China) (pp. 134-150). Beijing: Waiwen Chubanshe.

Wei, Y. (2002, December 13). Duli dongshi bei fa di yi an (The first case of an independent director being fined), Zhongguo Lüshi Wang (Chinese Lawyer Net). Available: http://www.chineselawyer.com.cn/article/ 200212135599.html.

Wruck, K. (1989). Equity ownership concentration and firm value. Journal of Financial Economics, 23, 3-28. 
Wu, G. (2002, November 20). Cong Lu Jiahao an fansi duli dongshi zhidu (Reflections on the independent director system from the Lu Jiahao case). Jiancha Ribao (Procuratorate Daily).

Xu, X., \& Wang, Y. (1999). Ownership structure and corporate governance in Chinese stock companies. China Economic Review, 10, 75-98.

Yin, W. (1999). Qiye jituan shangshi gongsi de guquan jiegou gaizao (Reform in the equity structure of listed enterprise group companies). In Zhongguo (Hainan) Gaige Fazhan Yanjiu Yuan [China (Hainan) Reform and Development Institute] (Ed.) Zhongguo gongsi zhili jiegou (The structure of corporate governance in China) (pp. 98-111). Beijing: Waiwen Chubanshe.

Yu, Y. (2001, May/June). Da gudong kongzhixing gongsi zhili de xiaolü pingjia (An assessment of the efficiency of corporate governance with a dominant shareholder). Caijing Kexue (Financial Science), No. 3, 50-53.

Zhang, J., \& Xu, S. (2003, July 14). 196 jia zhongyang qiye da zhenghe: Yanchu kaishi le (Big reorganization of 196 central enterprises: The performance has begun). 21 Shiji Jingii Baodao (21st Century Economic Report).

\section{Legislation}

Company Law: Zhonghua Renmin Gongheguo Gongsi FA (Company Law of the People's Republic of China). Adopted December 29, 1993. Effective July 1, 1994.

Partnership Law: Zhonghua Renmin Gongheguo Hehuo Qiye Fa (Partnership Enterprise Law of the People's Republic of China). Adopted February 23, 1997. Effective August 1, 1997.

Village and Township Enterprise Law: Zhonghua Renmin Gongheguo Xiang-Zhen Qiye Fa (Village and Township Enterprise Law of the People's Republic of China). Adopted October 29, 1996. Effective January 1, 1997. 